\title{
DEVELOPMENT OF A COMPETENCY MODEL OF MANAGERS AND EXPERTS IN THE HUMAN RESOURCES MANAGEMENT IN THE HOLDINGS OF THE AGRICULTURAL SECTOR
}

\begin{abstract}
The development of a set of professional competencies for managers and experts in the human resources management requires purposeful activity to improve the particular knowledge, skills and abilities. Their development has a direct or indirect impact on the results of the production and business operations of the agricultural holdings in the sector. This makes it necessary to investigate the levels of development of the professional competencies of the managers and experts on human resources management, by revealing opportunities for their sophistication and management.

The purpose of this article is to analyse the status and development of the professional competencies of the managers and the human resources management through assessment of their role in increasing production and economic efficiency of the farms in the agricultural sector.
\end{abstract}

Keywords: professional competency, efficiency, human resources management, agricultural sector.

\section{Introduction}

The development of a set of competencies supporting the realisation of the human resources in the agricultural sector requires purposeful activity to improve certain skills and abilities. They are the lingua franca in which the employers and employees communicate, thus showing the quality of the social and personal orientation of the human capital on the farms of the agricultural sector. Along with the development of the changes occurring in the sector, the requirements for the workforce grow and change, too. 
In recent years, the development of the professional competencies in the agrarian sector is increasingly linked to the process of performance, evaluation and career development of the human resources. Their development requires purposeful activity to improve specific knowledge, skills and abilities. The analysis of the status and trends in the development of professional competencies of the human resources in the agricultural sector in Bulgaria reveals a number of opportunities for their effective use and management.

In the environment of a rapid uptake of new techniques and technologies, demanding ever increasing requirements to the workforce, the managers (and especially the team leaders) need professional advice regarding work communication and interaction. At the same time, a number of key management activities of the human resources remain underdeveloped due to lack of structural units to serve them. This requires targeted work for the establishment and restructuring of departments for human resources management at medium and large-sized farms. Their main activity must be related to the support of the managers from other departments and the development of the main activities of the human resource management. At small-scale farms in the agricultural sector, the team managers have the power to decide on the activities regarding human resource management. This places additional demands on their training, qualifications and motivation to carry out the additional activities.

Exactly for this reason, the development of a set of professional competencies in the managers and experts in the human resources management requires purposeful activity to improve the particular knowledge, skills and abilities. Their development has a direct or indirect impact on the results of the production and business operations of the agricultural holdings in the sector. This makes it necessary to investigate the levels of development of the professional competencies of the managers and experts on human resources management, by revealing opportunities for their sophistication and management.

In this regard, the study of the level of professional skills of the managers and experts in human resources management on the profitable farms can help clarify the importance of the relationship between the development and improvement of the competencies and the final economic result.

The purpose of this article is to analyse the status and development of the professional competencies of the managers and the human resources management, through assessment of their role in increasing production and economic efficiency of the farms in the agricultural sector.

The article is structured in two main sections. The first involves analysis of the production competencies, explores the relationships and their links with the production and economic performance. The second section presents a model of professional competencies that are particularly important to achieve high economic performance at farms from the agricultural sector. 


\section{Materials and methods}

The opinions of owners and managers in 78 different in size, status and ownership holdings in the agricultural sector were studied and analysed to evaluate the state of the professional competencies of the managers and experts in the human resources management, which influence and interact with the production and economic performance. Most of them are located in Plovdiv, Haskovo and Pazardzhik municipalities.

The selection of the farms is based on the formation of human resources management units and their positive economic results, i.e. profit realised for the last three years preceding the survey. The impact and interaction of the professional competencies, influencing the rate of the profit in the agricultural holdings, are examined using a correlation analysis by the method of Pearson.

The participants of the study had previously received a list of 20 major groups of professional competency and their concise definition and description (Table 1). They were asked to rank them on a five-point scale, namely: 1 - not important, 2 - somewhat important, 3 -important, 4 - very important, 5 -extremely important.

The actual list has been prepared for the purposes of the study, in which the following were taken into account:

- Key competencies formulated by the European Commission (The Definition and Selection of Key Competencies);

- Preliminary analysis of similar studies in Europe and around the world in recent years (Employers' perception of graduate employability. Flash Eurobarometer, 2010; Ready to grow: business priorities for education and skills. Education and skills survey, 2010);

- Overview of the most frequently mentioned skills and qualities that are required from applicants in job advertisements;

- Consultations with employers, educational experts and counsellors who helped summarising the skills in 20 groups.

The second section presents a model of the professional competencies of the human resources. It identifies those which are particularly important to achieve high economic performance by the farms from the agricultural sector. To build this model, we implemented the Path-coefficient analysis. In this method, it is possible to combine the correlation, regression and structural analysis. This makes it one of the most appropriate methods for the study of relationships as Path-analysis examines not only direct but also indirect links between the state of the professional competencies of managers and experts in human resources management and the economic performance of the farms. Thus, those with the greatest impact are evaluated and those with little impact are rejected.

The study covers the period between July - October 2014. The data and information are collected through direct contacts and filling questionnaires specifically developed for the analysis. To further clarify the information, interview method was used. Processing and data analysis is done with the use of the statistical package SPSS 13.0 and Microsoft Office (Word, Excel, Power Point). 
Description of the main groups of professional competency

\begin{tabular}{|c|c|c|}
\hline No. & Competency & Description \\
\hline 1 & Adaptability & $\begin{array}{l}\text { Ability to adapt to the corporate culture, flexibility, quick orientation } \\
\text { to the demands of the changing environment, including the ability to } \\
\text { work under pressure and tight deadlines }\end{array}$ \\
\hline 2 & $\begin{array}{l}\text { Readiness and } \\
\text { willingness to learn }\end{array}$ & $\begin{array}{l}\text { Receptivity, curiosity, desire for self-improvement, seeking } \\
\text { and receiving feedback }\end{array}$ \\
\hline 3 & Loyalty & Ethical attitude, honesty, integrity \\
\hline 4 & Efficiency & Ability to cope with work tasks with good results \\
\hline 5 & Computer skills & Using word processors, spreadsheets, Internet applications \\
\hline 6 & Leadership skills & $\begin{array}{l}\text { Skills in planning, managing and motivating people, skills } \\
\text { in decision-making, negotiation, etc. }\end{array}$ \\
\hline 7 & Mathematical skills & Working with numbers, accuracy, methodical skills, precision \\
\hline 8 & $\begin{array}{l}\text { Ability to work } \\
\text { in a team }\end{array}$ & $\begin{array}{l}\text { Cooperation, conflict resolution, good interpersonal relations, } \\
\text { sociability, ability to build relationships }\end{array}$ \\
\hline 9 & Motivation & Positive work attitude, enthusiasm \\
\hline 10 & Professional skills & $\begin{array}{l}\text { Specific skills and knowledge of the professional field, } \\
\text { an adequate idea of the work }\end{array}$ \\
\hline 11 & Communication skills & Clear, convincing and literate expression in oral and written form \\
\hline 12 & Critical attitude & Analytical skills, logic, impartiality, accuracy \\
\hline 13 & Office skills & $\begin{array}{l}\text { Finding and organising information, documents, data; } \\
\text { work habits and use of office equipment }\end{array}$ \\
\hline 14 & $\begin{array}{l}\text { Entrepreneurial } \\
\text { skills }\end{array}$ & $\begin{array}{l}\text { Initiative, entrepreneurship, business knowledge and insight, deter- } \\
\text { mination, ability to make decisions and take risks }\end{array}$ \\
\hline 15 & $\begin{array}{l}\text { Self-presentation } \\
\text { skills }\end{array}$ & $\begin{array}{l}\text { Skills for successful performance (including in a job application } \\
\text { and interview), confidence in one's own skills, positivity, conviction, } \\
\text { knowledge of business communication }\end{array}$ \\
\hline 16 & Creativity & Creativity, initiative, ingenuity, lateral thinking \\
\hline 17 & Technical skills & Specific skills to use specialised software programmes and equipment \\
\hline 18 & Client attention skills & $\begin{array}{l}\text { Responsiveness, empathy, positive attitude, tact, tolerance, } \\
\text { patience, attentiveness }\end{array}$ \\
\hline 19 & Self-management skills & Responsibility, independence, organisation of time and work tasks \\
\hline 20 & Multilingual abilities & $\begin{array}{l}\text { Use (written and spoken) of a foreign language, intercultural } \\
\text { experience and knowledge }\end{array}$ \\
\hline
\end{tabular}

\section{Results and discussion}

Research on the professional competencies of the managers and experts in the human resources management, influencing and interacting with the economic performance of the farms in the agricultural sector

The data analysis shows that in the holdings of the agricultural sector Professional training $(\mathrm{R}=0.836$ at $\alpha=0.01)$ has the greatest impact on the final 
economic results (Table 2). Its impact is particularly intense with the managers of the human resources management. They show a very high correlation coefficient of 0.863 , statistically proven at $\alpha=0.01$. The importance of Professional training is demonstrated also for the experts $(\mathrm{R}=0.794$ at $\alpha=0.01)$.

Of particular importance for the positive economic results is Readiness and willingness to learn. The data show that this competency affects most significantly the experts in the human resources management $-\mathrm{R}=0.814$ at $\alpha=0.01$. Similar results were noted for the managers of the surveyed farms $(R=0.703$ at $\alpha=0.01)$.

Table 2

Impact of the professional competencies of the managers and experts in the human resources management on the economic situation of the farms in the agricultural sector

Professional competency

Correlation coefficient

\begin{tabular}{lccc}
\cline { 2 - 4 } Professional competency & Total & Managers & Experts \\
\hline Adaptability & $0.538^{\mathrm{a}}$ & $0.496^{\mathrm{a}}$ & $0.569^{\mathrm{a}}$ \\
Readiness and willingness to learn & $0.799^{\mathrm{b}}$ & $0.703^{\mathrm{b}}$ & $0.814^{\mathrm{b}}$ \\
Loyalty & 0.411 & 0.376 & $0.436^{\mathrm{a}}$ \\
Efficiency & $0.611^{\mathrm{b}}$ & $0.623^{\mathrm{b}}$ & $0.589^{\mathrm{b}}$ \\
Computer skills & 0.417 & 0.423 & $0.541^{\mathrm{a}}$ \\
Leadership skills & 0.278 & 0.296 & 0.278 \\
Mathematical skills & 0.193 & 0.104 & 0.253 \\
Ability to work in a team & $0.706^{\mathrm{b}}$ & $0.676^{\mathrm{b}}$ & $0.731^{\mathrm{b}}$ \\
Motivation & $0.576^{\mathrm{b}}$ & $0.598^{\mathrm{b}}$ & $0.596^{\mathrm{b}}$ \\
Professional skills & $0.836^{\mathrm{b}}$ & $0.863^{\mathrm{b}}$ & $0.794^{\mathrm{b}}$ \\
Communication skills & $0.716^{\mathrm{b}}$ & $0.768^{\mathrm{b}}$ & $0.614^{\mathrm{b}}$ \\
Critical attitude & $0.524^{\mathrm{a}}$ & $0.624^{\mathrm{b}}$ & 0.416 \\
Office skills & 0.397 & 0.361 & 0.411 \\
Entrepreneurial skills & $0.477^{\mathrm{a}}$ & $0.483^{\mathrm{a}}$ & $0.455^{\mathrm{a}}$ \\
Self-presentation skills & $0.496^{\mathrm{a}}$ & $0.467^{\mathrm{a}}$ & 0.421 \\
Creativity & $0.669^{\mathrm{b}}$ & $0.763^{\mathrm{b}}$ & $0.561^{\mathrm{a}}$ \\
Technical skills & $0.599^{\mathrm{b}}$ & 0.433 & $0.714^{\mathrm{b}}$ \\
Client attention skills & 0.394 & 0.419 & 0.351 \\
Self-management skills & $0.663^{\mathrm{b}}$ & $0.728^{\mathrm{b}}$ & $0.557^{\mathrm{a}}$ \\
Multilingual abilities & 0.389 & $0.471^{\mathrm{a}}$ & 0.315 \\
Respondents, \% & 100 & $43.7^{\mathrm{a}}$ & 56.3
\end{tabular}

${ }^{\text {a }}$ Correlation is significant at the 0.05 level;

${ }^{\mathrm{b}}$ Correlation is significant at the 0.01 level.

Source: own calculations. 
The following professional competencies have a deep impact on the final economic results of the agricultural holdings: Communication skills $(\mathrm{R}=0.716)$; Ability to work in a team $(\mathrm{R}=0.706)$; Creativity $(\mathrm{R}=0.669)$; Self-management skills $(\mathrm{R}=0.663)$; Efficiency $(\mathrm{R}=0.611)$; Motivation $(\mathrm{R}=0.576)$ Technical skills $(\mathrm{R}=0.599)$. The high correlation coefficients statistically proven at $\alpha=0.01$, reveal their role in achieving higher production and economic results in the farms in agriculture. Strong correlation with the profit is seen with Adaptability ( $\mathrm{R}=$ 0.538 at $\alpha=0.05)$, Critical thinking $(\mathrm{R}=0.524$ at $\alpha=0.05)$, Self-presentation skills $(\mathrm{R}=0.496$ at $\alpha=0.05)$ and Entrepreneurial skills $(\mathrm{R}=0.477$ at $\alpha=0.05)$.

For the managers responsible for the human resources management in the agricultural holdings, as particularly important for the increase in production and economic results stand Communication skills $(\mathrm{R}=0.768)$, Creativity $(\mathrm{R}=0.763)$, Self-management skills $(\mathrm{R}=0.728)$, Critical thinking $(\mathrm{R}=0.624)$, Efficiency $(\mathrm{R}=0.623)$, Motivation $(\mathrm{R}=0.598)$. Their interaction with the profit shows high correlation coefficients statistically proven at $\alpha=0.01$. The following also have an important role in improving the economic performance of these farms: Entrepreneurial skills, Adaptability, Multilingual skills and Self-presentation skills.

Similar are the results of the experts from the units of the human resources management. A strong correlation is detected among the following professional competencies: Ability to work in a team $(\mathrm{R}=0.731$ at $\alpha=0.01)$, Technical skills ( $\mathrm{R}=0.714$ at $\alpha=0.01)$, Communication skills $(\mathrm{R}=0.614$ at $\alpha=0.01)$, Motivation $(\mathrm{R}=0.596$ at $\alpha=0.01)$ and Efficiency $(\mathrm{R}=0.589$ at $\alpha=0.01)$ with the high production and economic performance of the farms in the agricultural sector.

From the present data, it can be concluded that in the study of the interconnections and relationships of the professional competencies of the managers and experts in the human resources management with the production and economic performance of the surveyed farms, a number of similar results are observed. Professional training, Readiness and willingness to learn, Ability to work in a team, Communication skills, Efficiency and Motivation are skills which are essential for making a profit in the holdings of the agricultural sector.

A certain difference in the strength of the effect is observed in terms of Critical thinking, Creativity, Multilingual skills and Self-management skills. They are rated as particularly important for the managers of the surveyed farms, while for the experts, their influence is weaker.

For the experts, the link between Computer skills, Technical skills and Loyalty with the profit is statistically proven, while for the managers these competencies are not placed in the foreground.

In the analysis of the other competencies a statistically proven relationship between them and the profit for the period of the study was not found. Medium and low correlation coefficients were reported. Mathematical skills were highlighted as the least significant to achieve positive economic results of the agricultural holdings. 
The current analysis shows the relationship and the strength of the impact of the professional competencies of the managers and experts in the human resources management on the economic performance of the farms in the agricultural sector. On the basis of this analysis, a combination of skills, which have the greatest impact on the economic performance in these farms, can be offered.

Modelling of the professional competencies of the managers and experts in the human resources management, which influence directly or indirectly the high economic performance of the farms in the agricultural sector

The method of Path-analysis was implemented in the research concerning the strength of impact of both direct and indirect links of the professional competencies on the economic situation of the farms in the agricultural sector. This method evaluates only those competencies which have the most profound impact on the economic performance, and the weak ones are removed. The obtained results of the Path-analysis are shown in Tables 3 and 4.

Table 3

Direct and indirect effects of the professional competencies of the managers in the human resources management, affecting the economic situation of the farms in the agricultural sector

\begin{tabular}{lcc}
\hline \multirow{2}{*}{\multicolumn{1}{c}{ Professional competency }} & \multicolumn{2}{c}{ Path-coefficients } \\
\cline { 2 - 3 } & Direct effect & Indirect effect \\
\hline Professional skills & 0.651 & 0.212 \\
Readiness and willingness to learn & 0.860 & -0.157 \\
Creativity & -0.438 & 1.201 \\
Efficiency & 0.451 & 0.172 \\
Self-presentation skills & 0.724 & -0.257 \\
Adaptability & 0.403 & 0.093 \\
Multilingual abilities & 0.839 & -0.368 \\
Ability to work in a team & 0.497 & 0.179 \\
Communication skills & 0.897 & -0.129 \\
Motivation & 0.507 & 0.091 \\
Critical attitude & -0.369 & 0.993 \\
Self-management skills & 0.466 & 0.262 \\
Entrepreneurial skills & -0.228 & 0.711 \\
Loyalty & 0.705 & -0.329
\end{tabular}

Source: own calculations.

The information in Table 3 shows that some of the professional competencies of the managers in the human resources management have a positive direct and indirect impact on the economic situation of the farms in agricultural sector. These 
competencies are assessed as very positive. These include Professional training, Efficiency, Adaptability and Ability to work in a team. The professional competencies Self-management skills and Motivation are also outlined as very positive.

Self-presentation skills, Readiness and willingness to learn, Communication skills, Multilingual skills and Loyalty have a direct positive effect on the economic situation of the farms in the agricultural sector. The indirect effect of this group of professional competencies on the economic performance, however, is negative.

The third group of professional competencies, which includes Creativity, Critical thinking and Entrepreneurial skills, has a direct negative impact on the economic performance of the farms in the agricultural sector. However, its indirect influence is very positive. The coefficient of the indirect effect exceeds that of the direct and the ultimate impact of these competencies is also positive.

Table 4

Direct and indirect effects of the professional competencies of the experts in the human resources management, affecting the economic situation of the farms in the agricultural sector

\begin{tabular}{lcc}
\hline \multirow{2}{*}{\multicolumn{1}{c}{ Professional competency }} & \multicolumn{2}{c}{ Path-coefficients } \\
\cline { 2 - 3 } Professional skills & Direct effect & Indirect effect \\
Readiness and willingness to learn & 0.536 & 0.258 \\
Creativity & 0.690 & 0.124 \\
Efficiency & -0.367 & 0.928 \\
Adaptability & 0.826 & -0.237 \\
Computer skills & 0.895 & -0.326 \\
Ability to work in a team & 0.463 & 0.078 \\
Communication skills & 0.592 & 0.139 \\
Motivation & 0.820 & -0.206 \\
Technical skills & 0.497 & 0.099 \\
Self-management skills & -0.179 & 0.893 \\
Entrepreneurial skills & 0.279 & 0.278 \\
Loyalty & -0.316 & 0.771 \\
& 0.570 & -0.134
\end{tabular}

Source: own calculations.

Table 4 presents the direct and indirect effects which have the professional skills of the experts in the human resource management on the production and economic results of the farms in the agricultural sector. Positive direct and indirect effects were seen in Professional training, Readiness and willingness to learn, Computer skills and Ability to work in a team. As very positive competencies emerge Self-management skills and Motivation. 
The direct positive impact of the professional competencies Efficiency, Adaptability, Communication skills and Loyalty of the experts in the human resources management on the farms in the agricultural sector, is reduced to some extent by the negative indirect effect of these.

The third group, consisting of professional competencies with direct negative and indirect positive effect, include Technical and Entrepreneurial skills and Creativity. Although the direct impact of these competencies on the final economic result is negative, the indirect positive effect is stronger, leading to a final positive effect.

Modelling of professional competencies, which have a positive influence on the economic situation, help build a comprehensive system for the selection, training and professional development of managers and experts in the human resources management on the farms in the agricultural sector (Figure 1).

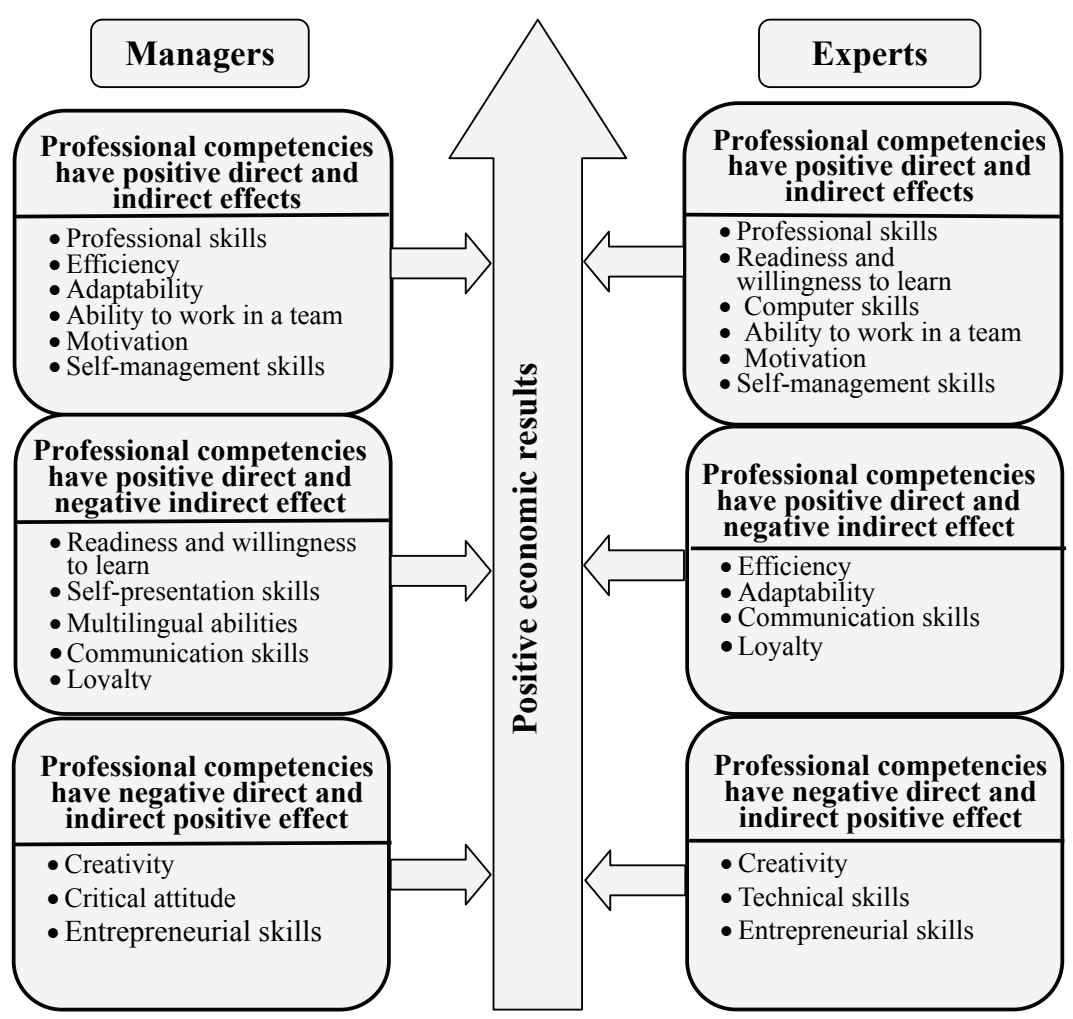

Fig. 1. Model of the professional competencies of the managers and experts in the human resources management which have direct and indirect effects on the economic situation of the farms in the agricultural sector.

Source: own elaboration. 


\section{Conclusions}

The construction of a set of competencies requires focused activities to improve certain knowledge, skills and abilities. They have a direct or indirect impact on the results of the production and business operations of the agricultural holdings in the sector. Therefore, it is essential to examine the condition of professional competencies by revealing opportunities for their effective use and management.

The analysis showed the relationship and the strength of the impact of the professional competencies presented on the economic situation of the farms in the agricultural sector. On the basis of this analysis, we can offer a combination of skills which have the greatest impact on the economic performance of the farms.

Modelling of professional competencies, which positively influence the economic situation, helps build a comprehensive system for the selection, training and professional development of managers and employees on the farms in the agricultural sector. 


\section{Literature:}

Bencheva, N., Tepavicharova, M. (2011). A study of middle management's competences. CEA, Volume VIII, Plovdiv, Bulgaria, pp. 90-102.

Bencheva, N., Tepavicharova, M. (2011). Autodidactic instruments for increasing the expertise of managers and staff. National Conference "Learning from the crisis - lessons learned, recommendations and strategies”, CEA, 13 May 2011, Plovdiv, Bulgaria, pp. 155-167.

Employers' perception of graduate employability (2010). Flash Eurobarometer. Retrieved from: http://ec.europa.eu/public_opinion/flash/fl_304_en.pdf.

Exploring the role of professional competence in the farms of the agricultural sector. July October 2014.

Graduate Employability: What do employers think and want? (2008). Retrieved from: http:// ec.europa.eu/education/higher-education/doc/business/graduate_en.pdf

Lisbon Council. Europe 2020: Why Skills are Key for Europe's Future. Retrieved from: http://www.lisboncouncil,net/publication/publication/54-skillseuroprsfuture.html.

Ready to grow: business priorities for education and skills. Education and skills survey (2010). Retrieved from: http://www.cbi.org.uk/ndbs/content.nsf/802737AED3E3420580256706005390AE/C4393B860D00478E802576C6003B0679

Tepavicharova, M. (2012). Competencies as an instrument for human resource management in small and medium-sized enterprises in the agricultural sector. Article in the Proceedings of the Tenth National Youth Scientific and Practical Conference, Sofia, Bulgaria, pp. 221-229.

Tepavicharova, M., Bencheva, N. (2013). Comparative analysis of the evaluation of professional competence at a sectoral level. International Conference "Eastern European transition and socio-economic stratification", CEA, 25-26 October 2013, Plovdiv, Bulgaria, pp. 265-272.

The Definition and Selection of Key Competencies. Retrieved from: http://www.oecd.org/dataoecd/47/61/35070367.pdf 
NELLY BENCHEVA

MILENA TEPAVICHAROVA

Uniwersytet Rolniczy

Płowdiw, Bułgaria

\title{
OPRACOWANIE MODELU KOMPETENCYJNEGO DLA KIEROWNIKÓW I EKSPERTÓW \\ Z ZAKRESU ZARZĄDZANIA ZASOBAMI LUDZKIMI \\ W GOSPODARSTWACH SEKTORA ROLNEGO
}

\begin{abstract}
Abstrakt
Opracowanie zestawu kompetencji zawodowych dla kierowników i ekspertów z zakresu zarzadzania zasobami ludzkimi wymaga celowego działania zmierzajacego do poprawy konkretnej wiedzy, konkretnych umiejęności i zdolności. Ich rozwój ma bezpośredni lub pośredni wpływ na wyniki produkcyjne i działalność ekonomiczna gospodarstw rolnych $w$ sektorze. Przez to konieczne jest zbadanie poziomów rozwoju kompetencji zawodowych kierowników i ekspertów z zakresu zarzadzania zasobami ludzkimi poprzez ujawnienie możliwości ich wyrafinowania i zarzadzania.

Niniejszy artykut ma na celu analize statusu i rozwoju kompetencji zawodowych kierowników i ekspertów z zakresu zarządzania zasobami ludzkimi poprzez ocene ich roli $w$ zwiększaniu produkcji $i$ wydajności ekonomicznej gospodarstw rolnych $w$ sektorze rolnictwa.
\end{abstract}

Słowa kluczowe: kompetencje zawodowe, wydajność, zarządzanie zasobami ludzkimi, sektor rolny.

Zaakceptowano do druku - Accepted for print: 01.12.2016.

O ile nie jest to stwierdzone inaczej, wszystkie materiały na stronie są dostępne na licencji Creative Commons Uznanie Autorstwa 3.0 Polska. Pewne prawa zastrzeżone na rzecz Instytutu Ekonomiki Rolnictwa i Gospodarki Żywnościowej - PIB.

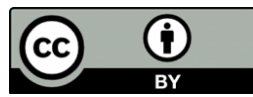

